\title{
What Do Data Mean for Pre-service Chemistry Teachers?
}

\author{
Nejla Gültepe \\ Correspondence: Nejla Gültepe, Dumlupınar University, Department of Science Education, Kütahya, Turkey
}

Received: March 11, 2016 Accepted: March 28, $2016 \quad$ Online Published: April 14, 2016

doi:10.11114/jets.v4i7.1449

URL: http://dx.doi.org/10.11114/jets.v4i7.1449

\begin{abstract}
This phenomologic study was carried out in order to determine how 63 pre-service chemistry teachers graduated from Chemistry Branch of Science Faculty in the pedagogical training program during 2013-2015 academic years defined the concepts of density and melting and boiling points and how they interpreted the data in micro levels. A diagnostic instrument for measurement consisting of six open-ended questions was prepared. Content analysis was performed and the results were given in frequency and percentage distribution category. Below 50\% of participants gave significant and correct answers to all of the questions about density, melting and boiling points and they interpreted the concepts of underlying data and units in micro levels correctly. It was established that most of the students could not go beyond formulas especially in the concept of density and they had misconceptions about the definitions of this concept and interpretion of the data related to density, melting and boiling points. Given the students' answers, it can be stated that the misconceptions were associated with the research concepts resulted from the misconceptions of preservice teachers about particle size, particle mass and intermolecular forces. It can be quite useful to present the practices of employing data and units for significant science education to students' attention during all stages of teaching.
\end{abstract}

Keywords: density, melting point, boiling point, misconception, chemistry education, pre-service teachers

\section{Introduction}

One of the chief goals of modern-day science education is also scientific literacy. The main aim of scientific literacy is to make self-confident and able individuals studied compulsory science classes keep pace with the world in which they live, understand facts and events they encounter, think straight in today's information age rather than make them expert in the field of science and technology. If this specific aim cannot be reached, members of the community can be destitute of positive thinking skill and may fall back on non-science areas instead of scientific solutions when trying to solve all kinds of problems. Educating a scientifically-literate generation with clear standpoints is an absolute necessity as learning the alphabet (Esme, 2004). Scientific literacy offers a certain perspective on being a qualified individual. From this point of view, it is well understood that qualified members who are able to produce knowledge are highly significant for the country and science classes are critically important in this process.

Scientific knowledge develops through "knowing", "performing" and "talking about" science (Lee \& Ertmer, 2006). This must convey true sense of science education as the primary target. In order to accomplish an effective science teaching - learning, environments should be created through methods which aim at educating individuals, who attain the scientific knowledge of this world and the scientific habits of the mind at the same time, support the teaching of the art of thinking, incorporate the instruction of thinking skills into daily classes, ensure the development of clear concepts based on experiences in mind and show how cause and effect relationship is analyzed (Gultepe \& K1lic, 2015; Inan \& Inan, 2015; Myers, Washburn, \& Dyer, 2004). The aim of scientific literacy is to realize the potential features of individuals and right now connect them with scientific methods (Tan \& Temiz, 2003).

In other words, these individuals should be aware that questions such as how do we know and what is the evidence are answered and understood (Arons, 1983 cited by Laugksch \& Spargo, 1996). Individuals with such thinking skills should have the adequacy of reasoning and decision-making (Friel \& Bright, 1998). Knowledge that people needed to make decisions not a long time ago was simple and ready. Today, as life keeps on getting more and more complicated, knowledge becomes more widespread and makes ambiguous. Therefore, learning and life achievement require a comprehension of how data are to be interpreted and manipulated efficiently. Within this context, expressing and interpreting data and units correctly are one of the basic skills that scientifical literate individuals should acquire. Without the comprehension of how samples are taken and data are analyzed, individuals cannot participate actively in the 
important modern-day political discussions related to environment, health services, educational quality and equality (Konold \& Higgins, 2003).

Data are the term used to refer to the raw numbers (facts and figures) that arise from the occurrence of an event physical, social, economic, geographical events that have the potential to produce numbers and figures. Data are derived from every activity. For instance, a car movement continuously produces data such as time taken, speed of the travel, fuel consumption, acceleration and deceleration and so on (Sharma, 2014).

Data without a unit is meaningless. A numerical value by itself does not mean anything. Therefore, a number, say 17 , means absolutely nothing by itself. The number starts to mean something by saying that is the temperature, etc. However, this does not describe the number completely. The following question will occur: "What does the number 17 represent regarding its magnitude? When the number is qualified by 'degree Celsius' or ${ }^{\circ}{ }^{\circ}$ ' units, then the units autmatically give new meaning to the number. The introduction of the unit automatically qualifies the temperature. The unit defines the magnitude of the data. A unit also allows a number to compare to other values.

Limited time and resources and improved decision making are critical to all areas of life in order to improve the quality of output from fixed resources. When put in an accurate form and shape, data offer information which feeds this need for improved decision making. In fact, in our everyday lives, all of us have been interpreting the data extensively to make our own decisions, for example, in choosing the suitable medicine or health practices, deciding where to live or judging education, policy and practice. As literate citizens of a democratic community, we are invited to reason with and interpret clever data. Paper and television news, nutrition, side effects of extensive drugs and upcoming election questionnaires are full of data we are to interpret smartly. Considering the data, we have to evaluate the reliability of what we see, read or hear and make critical and subtle distinctions when we think about the data we have been given (Rubin, 2005). The interpretation of data is the process through which inferences are drawn for analysis. In other words, the process of inferring and drawing conclusions through the interpretation of data is what data interpretation is all about (Sharma, 2010). Focusing on data is a specific thinking form that includes the skills of 21 st century, especially problem solving, critical and systematic thinking, creativity and communication. While interpreting data, what is understood is pointed out. This skill enables meaningful inference through reasoning, thus noticing relations between events and facts (Ango, 2002). It is the explanation why and how an event is based upon observation and assessment results. This is utilized in a wide range from a simple observation process to graph interpretation. Researches conducted in this way may come to right conclusions. If data is interpreted well enough, then the conclusions sound coherent (Altusoy, 2008).

Interpreting data is a process performed by the integration process of the skills of observation, classification, assessment, inference, estimation and hypothesis formation. All steps are utilized when data are interpreted (Gultepe \& K1lıc, 2015; Tatar, 2006). When interpreting data, the activity involves organizing, analyzing and accessing the data using some interpreting maps (air, contour), graphs, tables, news boards, photos and symbol lists. In classrooms where to think, the data are a usual part of the learning and teachers and students query whether the results are accurate, based on the following questions: Which evidence supports your standpoint? When did you find this evidence? Do you have all the evidence you need for the topic? What methods did you employ to reach the conclusions? Why did you interpret the facts as you did? (Swartz, 2000)

Educators have big responsibility for acquiring these skills. Whereas some innate features of students such as inquiry, curiosity, attention, observation and research develop in the hands of skilled teachers, the opposite situation yields utterly meaningless results (Miles, 2010). Some studies found that science process skills of teachers are not sufficient; teachers are neither knowledgeable enough about the content of some science process skills nor able to make use of them in their classes sufficiently (Inan, 2010; Karsl1, Sahin, \& Ayas, 2009; Pekmez, 2001). According to Oloruntegbe and Omoifo (2000), the teachers with attained and developed science process skills are more active in teaching these skills in their classrooms than the others. To conclude, teachers should have satisfactory science process skills and aim to have their students mastered them.

There is a considerable evidence suggesting that teachers' knowledge, understanding and thinking skills are linked to student learning and achievement (Hill, Ball, \& \& Schilling 2008). Therefore, in order to improve student learning, understanding and thinking skills, higher education institutions should first equip teachers with necessary knowledge and skills to educate their own students properly when they start teaching. They should also encourage students to apply their newly acquired knowledge and skills to a different context (Cimer, 2012). As Warburton (2008) suggested, the period of pre-service education and training is an ideal time to carry out interventions to promote effective teaching through challenging and to redirect student teachers' own misconceptions to achieve the desired outcomes.

Various studies have been conducted regarding conceptual understanding and misconceptions of pre-service science teachers and students of different grades in primary and secondary levels about density, melting and boiling points and science process skills (Gultepe, Yalcın-Celik, \& K1lıc, 2013; Osborne \& Cosgrove, 1983; Turpin, \& Cage, 2004), 
Because the correct expression of data and units in science education is one of the primary skills that students attain in order to become scientifically literate individuals, this study is quite important to determine how data and units on density, melting and boiling points are interpreted and evaluated and how data and units on concepts are linked with the concepts themselves. Within this context, the problem of the study conducted to establish what the data on density, melting and boiling points mean for pre-service chemistry teachers and how they interpret these data in micro-level was "how do pre-service chemistry teachers interpret data on density, melting and boiling points in micro-level?"

\section{Method}

The research is a phenomenological study within the framework of qualitative research. Phenomenology is a suitable research pattern to investigate phenomena which sound totally familiar but cannot comprehended completely A phenomenological approach is based on individual experiences. In such an approach, the researcher investigates the perception of the participants and meanings they ascribe to events or concepts. In phenomenological researches, data sources are the individuals or groups that experience or reflect the phenomenon on which relevant research is focused (Budak \& Budak, 2013).

Based on the views of pre-service chemistry teachers, phenomenological pattern was intented to establish how they interpreted data on the density, melting and boiling points, the changes or constancy of a matter depending upon the conditions of the density, melting and boiling points, to explain why the characteristics of these matters differ from each other and to examine the inferences about the statements of the participants in detail.

In this respect, 63 chemistry pre-service teachers completing successfully the initial teacher training at Chemistry Teaching of Dumlupınar University were included in the research sample. The period of study in all departments of faculty of science and letters and faculty of education all over the country is 4 years ( 8 semesters). There are two systems regarding the teacher training programs in Turkey in accordance with the legal regulations made in 2010. One of them is teacher training carried out by faculty of education; the other is teacher training through pedagogical formation programmes implemented for those graduated from faculty of science and letters graduates or for senior students of these faculties (Yıldirım \& Vural, 2014). Formation is a program where a teaching certificate is conferred on them after senior students (final year) or those graduated from the undergraduate program in faculties of science of various universities in Turkey have received field education and training courses for 9 months (two half-semester pedagogical formation training).

A diagnostic instrument for assessment was prepared by the researcher after compromising on three open-ended questions as data collection tool. The questions of the test were presented in the section findings. Two field instructors shared their opinions about the content validity of the test and the test was finalized after applying it to two postgraduates of science education graduated from chemistry and science departments. The test took 25 minutes to complete. The content analysis was performed and the results were presented as frequency and percentage distribution.

An inductive content analysis was performed to analyze the instrument of assessment. In the analyses, each question of the test was coded separately with similar statements and in the coding process two themes were composed for the statements as "correct and explained in micro level" and "incorrect and not explained in micro level" and the frequency and percentage distributions were established. Accordingly, the frequency of every question and student answers are presented below.

\section{Results}

Table 1 shows the frequency of the answers of pre-service teachers for Question 1.

Table 1. The frequency of the answers of pre-service teachers for Question 1

\begin{tabular}{|c|c|c|c|}
\hline \multicolumn{4}{|c|}{ Question 1a. The density of magnesium in its solid form at $20^{\circ} \mathrm{C}$ is $1.74 \mathrm{~g} \mathrm{~cm}^{-3}$. Figure out what the data mean. } \\
\hline Theme & $F$ & $\%$ & Sample answers \\
\hline $\begin{array}{l}\text { Correct and } \\
\text { explained answer in } \\
\text { micro-level }\end{array}$ & 18 & 28.57 & $\begin{array}{l}-\quad \text { the mass of its volume in } \mathrm{cm} \\
-\quad \mathrm{cm} \text { equals to } 1,74 \mathrm{gr} .\end{array}$ \\
\hline $\begin{array}{l}\text { Incorrect and not } \\
\text { explained answer in } \\
\text { micro- level }\end{array}$ & 45 & 71.34 & $\begin{array}{l}\text { - It gives the density of the matter. } \\
\text { - It informs about the mass of the matteb. } \\
\text { - } \quad \text { Masives the number of particles in } \mathrm{cm} \text {. } \\
\text { - It reminds of magnesium in } 1.74 \mathrm{~g} \mathrm{~cm}^{-3} . \text { Density is a non-characteristic } \\
\text { characteristic. }\end{array}$ \\
\hline
\end{tabular}

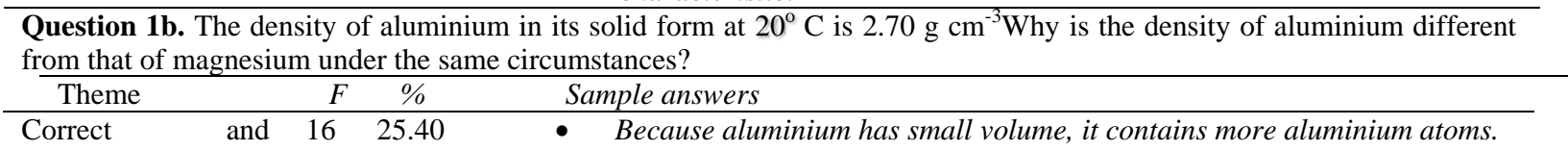




\begin{tabular}{|c|c|c|c|}
\hline $\begin{array}{l}\text { explained answer in } \\
\text { micro- level } \\
\text { Incorrect and not } \\
\text { explained answer in } \\
\text { micro- level }\end{array}$ & 47 & 74.60 & 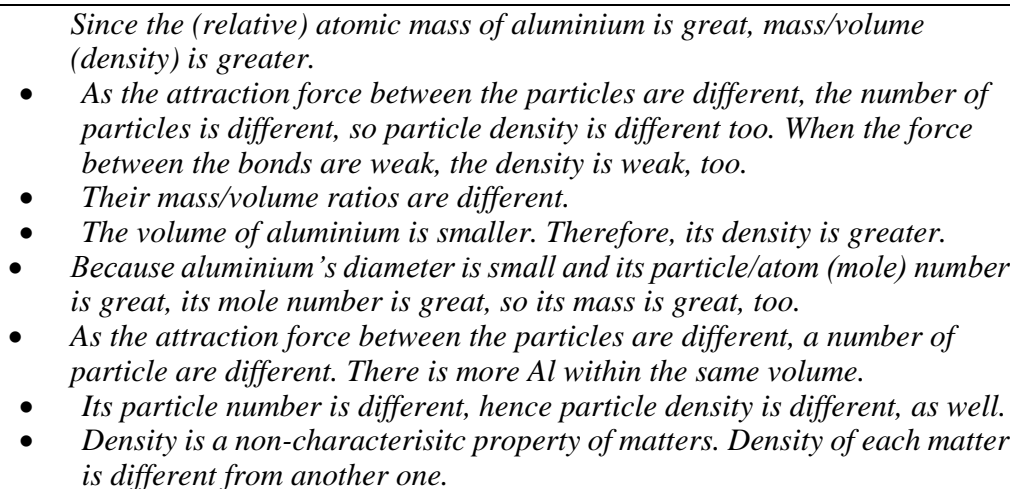 \\
\hline Metal $(\mathrm{Mg})$ & & Variable $\mathrm{A}_{1}$ & $\begin{array}{cc}\text { Variable } \mathrm{A}_{2} & \text { Variable } \mathrm{A}_{3}\end{array}$ \\
\hline Density $\left(\mathrm{gr} \mathrm{cm}^{-3}\right)$ & & 1.74 & 1.74 \\
\hline $\begin{array}{l}\text { Correct: } \\
\text { Reason: } \\
\text { Experiment } 2\end{array}$ & & Incorrect: & - \\
\hline Metal $(\mathrm{Mg})$ & & Variable $\mathrm{B}_{1}$ & Variable $\mathrm{B}_{3}$ \\
\hline Density $\left(\mathrm{gr} \mathrm{cm}^{-3}\right)$ & & 1.74 & 1.72 \\
\hline Correct : & & rrect: & \\
\hline
\end{tabular}

Reason:

The table above shows the data obtained as a result of two different experiments conducted in order to determine the factors that affect the density of magnesium metal. The data tables display the change in the density values of magnesium metal based upon a factor (variable). In Experiment 1, it can be observed that the density of magnesium metal is not dependent upon Variable A. In Experiment 2, the density of magnesium metal lessens depending upon Varible B. Do you think there is an error in the data tables? If yes, circle "correct" or "incorrect" and explain the reasons for your error. Say separately what your opinion is about two experiments.

Question 1c.

\begin{tabular}{|c|c|c|c|}
\hline Experiment 1 & $f$ & $\%$ & Sample answers \\
\hline $\begin{array}{l}\text { Correct and } \\
\text { explained answer in } \\
\text { micro-level }\end{array}$ & 16 & 25.40 & $\begin{array}{l}\text { - Correct. The density of the matter may not change when the mass or } \\
\text { volume has been altered. The temperature stays the same. Its mass is } \\
\text { increased. In this case, its volume increases, as well. The ratio stays } \\
\text { constant. }\end{array}$ \\
\hline $\begin{array}{l}\text { Incorrect and not } \\
\text { explained answer in } \\
\text { micro- level }\end{array}$ & 47 & 76.40 & $\begin{array}{l}\text { - Table } 1 \text { is correct, I suppose. Its temperatures change. } \\
\text { - Table } 1 \text { is correct. Density is a non characteristic property of matter. The } \\
\text { same matter has different densities in different states. So, it does not } \\
\text { change state in the first condition. }\end{array}$ \\
\hline Experiment 2 & $f$ & $\%$ & Sample answers \\
\hline $\begin{array}{l}\text { Correct and } \\
\text { explained answer in } \\
\text { micro- level }\end{array}$ & 15 & 23.80 & $\begin{array}{l}\text { - The data table in Experiment } 2 \text { is not correct, I guess. The density may } \\
\text { reduce. Because its temperatures may be increased, it expands. } \\
\text { - Correct. The pressure is increased. As the particles are farther than } \\
\text { before its density lessens. }\end{array}$ \\
\hline $\begin{array}{l}\text { Incorrect and not } \\
\text { explained answer in } \\
\text { micro- level }\end{array}$ & 48 & 76.20 & $\begin{array}{l}\text { - I do not agree with data table } 2 \text {, it is not correct. Density is a } \\
\text { characteristic property. No such thing occurs. Density increases with } \\
\text { contamination. But here it decreases. } \\
\text { Density of matters change with contamination. Matter with lower density } \\
\text { is added. It is possible, I think. }\end{array}$ \\
\hline
\end{tabular}

Approximately $25 \%$ of the pre-service teachers interpreted this question correctly regarding mass and volume variables in micro-level. In the first part of the question (1a), $11 \%$ of the pre-service teachers defined the density as the weight of the matter as $21 \%$ of them defined it as the number of particle in unit volume. $14.28 \%$ of them formulized did not explain in micro-level. $9.53 \%$ of them indicated that the densities of matters did not change and their reason was that density is the characteristic of matter. In the second part of the question (1b), the densities of different matters were compared and relationships were built with more particle numbers. $22.22 \%$ of them stated that the one with great force of attraction between the particles had more particle numbers and density. $14.28 \%$ of them stated that the density of the one with greater mass in the same volume was greater. $11.11 \%$ of them compared densities relating to particle volume independently from mass. $12.70 \%$ of them indicated that this is a memorized knowledge. Because density is the noncharacteristic property, the density of each matter is different from each other. In the third part of the question (1c), most of the pre-service teachers specified that the second data table is incorrect and the density of a pure substance do not change depending on physical factors. The pre-service teachers have read the data tables, identified variables, made comparisons and failed to interpret data correctly due to the misconceptions under which they labored. 
The second question aimed to investigate how pre-service teachers interpreted data on melting points and their explanation for the changes in melting points in micro-level. Table 2 below shows the frequency values of answers of the pre-service teachers for Question 2.

Table 2. The frequency values of answers of the pre-service teachers for Question

\begin{tabular}{|c|c|c|c|}
\hline Theme & $f$ & $\%$ & Sample answers \\
\hline $\begin{array}{l}\text { Correct and } \\
\text { explained answer in } \\
\text { micro- level }\end{array}$ & 18 & 28.57 & $\begin{array}{l}\text { - The temperature at which particles move from regular to irregular state } \\
\text { (under constant pressure). } \\
\text { - The temperature at which particles show liquidity characteristic with the } \\
\text { distancing of the particles from their attraction field. }\end{array}$ \\
\hline $\begin{array}{l}\text { Incorrect and not } \\
\text { explained answer in } \\
\text { micro- level }\end{array}$ & 45 & 71.43 & $\begin{array}{l}\text { - The point where melting and saturation occur. } \\
\text { - It is a noncharacteristic property, it represents magnesium. } \\
\text { - It is the temperature necessary for the melting process. It is a non- } \\
\text { characteristic property of matter. } \\
\text { - It informs about the weight of the matter. }\end{array}$ \\
\hline
\end{tabular}

Question 2b. The usual melting point of aluminium in its solid form is $660^{\circ} \mathrm{C}$. Why do aluminium and magnesium metals have the different melting points under the same circumstances? $\left({ }_{12} \mathrm{Mg},{ }_{13} \mathrm{Al}\right)$

\begin{tabular}{|c|c|c|c|}
\hline Theme & $f$ & $\%$ & Sample answers \\
\hline $\begin{array}{l}\text { Correct and } \\
\text { explained answer in } \\
\text { micro- level }\end{array}$ & 16 & 25.40 & $\begin{array}{l}\text { - The higher the attraction force between particles, the higher their melting } \\
\text { and boiling points. } \\
\text { - The number of aluminium proton is greater. Its diameter is small. Its } \\
\text { attraction force is greater. }\end{array}$ \\
\hline $\begin{array}{l}\text { Incorrect and not } \\
\text { explained answer in } \\
\text { micro- level }\end{array}$ & 47 & 34.60 & $\begin{array}{l}\text { - In the periodic table, the volume of the metals decreases from left to right, } \\
\text { particle numbers increase and so the melting point gets higher. } \\
\text { Because the atomic mass of aluminium is great, its density is greater. Its } \\
\text { melting point is higher. } \\
\text { - Its volume increases as the force of attraction per electron decreases when } \\
\text { electron number in the last layer increases. Yet the melting point of } \\
\text { aluminium is higher as mass increases more. } \\
\text { Al is denser because its particle number is more and it has more bonds. It is } \\
\text { required more energy to break off them. For this reason, the melting point } \\
\text { of aluminium is higher. } \\
\text { - The melting point of non-metals is higher than that of metals. Aluminium is } \\
\text { a non-metal. Therefore, the melting point of aluminium is higher. } \\
\text { - Containers made of aluminium are heat-proof. Therefore, the melting } \\
\text { point of aluminium is higher. } \\
\text { Magnesium is a more active metal. An active metal is softer. Aluminium is } \\
\text { denser and harder. Therefore, it has a higher melting point. } \\
\text { The one with greater mass has more density and higher melting point. Both } \\
\text { are non- characteristics property. They are connected with each other. } \\
\text { Aluminium melts at a higher temperature. }\end{array}$ \\
\hline
\end{tabular}

Question 2c.

Experiment 1

\begin{tabular}{llll}
\hline Metal $(\mathrm{Mg})$ & Variable $\mathrm{A}_{1}$ & Variable $\mathrm{A}_{2}$ & Variable $\mathrm{A}_{3}$ \\
\hline Melting Point $\left({ }^{\circ} \mathrm{C}\right)$ & 650 & 650 & 650 \\
\hline $\begin{array}{l}\text { Correct: } \\
\text { Reason: }\end{array}$ & Incorrect: & & \\
& & Experiment 2 & \\
\hline Metal $(\mathrm{Mg})$ & & Variable $\mathrm{B}_{2}$ & Variable $\mathrm{B}_{3}$ \\
\hline Melting Point $\left({ }^{\circ} \mathrm{C}\right)$ & Variable $\mathrm{B}_{1}$ & 648 & 646 \\
\hline $\begin{array}{l}\text { Correct: } \\
\text { Reason: }\end{array}$ & Incorrect: & & \\
\end{tabular}

The table above shows the data obtained as a result of two different experiments conducted to identify the factors that affect the melting point of magnesium metal. The data tables display the change in the melting points of magnesium metal based upon a factor (variable). In Experiment 1, it can be observed that the melting point of magnesium metal is not dependent upon Variable A; in Experiment 2, the melting point of magnesium metal lessens depending upon Varible B. Do you think there is an error in the data tables? If yes, circle "correct" or "incorrect" and explain the reasons for your error. Say separately what your opinion is abour two experiments. 


\begin{tabular}{lllll}
\hline Experiment $1 \quad$ & $f$ & $\%$ & Sample answers \\
\hline $\begin{array}{l}\text { Correct and } \\
\text { explained answer in } \\
\text { micro-dimension }\end{array}$ & 39.68 & $\bullet$ & $\begin{array}{l}\text { I think the first table is correct. Even if the amount, volume of magnesium } \\
\text { and the power of heater are changed, the melting points may stay constant. }\end{array}$ \\
$\begin{array}{l}\text { Incorrect and not } \\
\text { explained answer in } \\
\text { micro- level }\end{array}$ & 60.32 & $\bullet$ & $\begin{array}{l}\text { Ithink the first table is correct and the second one is incorrect. Melting } \\
\text { point is a non characteristic property. Therefore, the melting point of a } \\
\text { matter never changes. }\end{array}$ \\
& $\bullet \begin{array}{l}\text { The first table is correct. Because temperature does not change, the } \\
\text { melting point does not, either. } \\
\text { Melting points of pure substances do not change depending on physical } \\
\text { alterations, that's why the first table is correct. }\end{array}$
\end{tabular}

\begin{tabular}{|c|c|c|c|}
\hline Experiment 2 & $f$ & $\%$ & Sample answers \\
\hline $\begin{array}{l}\text { Correct and } \\
\text { explained answer in } \\
\text { micro- level }\end{array}$ & 2 & 3.18 & $\begin{array}{l}\text { - I guess the second table is correct. When pressure is increased, melting } \\
\text { point drops. Because as matter melts, its volume increases. Melting gets } \\
\text { easier. The variable here is pressure. }\end{array}$ \\
\hline $\begin{array}{l}\text { Incorrect and not } \\
\text { explained answer in } \\
\text { micro- level }\end{array}$ & 61 & 36.82 & $\begin{array}{l}\text { - The second table is incorrect. Because melting and boiling points are } \\
\text { characteristic features. They do not change in any way. } \\
\text { Factors such as contamination, temperature and pressure affect the } \\
\text { melting point. Variable is one of them. Contamination drops the melting } \\
\text { point of the matter. Variable may be the amount of a foreign substance that } \\
\text { is added. } \\
\text { The melting point of magnesium drops if there occurs a mixture of metal } \\
\text { at a lower melting point. The second table is correct. }\end{array}$ \\
\hline
\end{tabular}

Most of pre-service teachers $(25.40 \%)$ have the misconception that melting points cannot be changed since they are a characteristic feature. $25 \%$ of them have the misconception that contamination causes a change in the melting point of the matter (in an alloy mixed one metal with another). In fact, the bond structures of two atoms mixing with each other collapse and the location of the atoms in the alloy demonstrates regularity. The atoms in the alloy enter into the attraction fields of each other and the attraction force between them differ from pure metal. With the addition of another metal, the matter becomes a mixture and a change occurs in the features of conductivity and hardness, as well as the melting point. Besides, $45 \%$ of the pre-service teachers failed to explain what melting temperature value means correctly in micro-level. In the second part of the question, most of them shared the misconception that the more a matter has particle number (particle density), the more it has dense when compared the density of magnesium metal with that of aluminum metal.

In Question 3, the opinions of pre-service teachers were received regarding what boiling temperature means and why the boiling points of different liquids may differ. Question 3 and its answers are presented in Table 3

Table 3. The frequency values of answers of the pre-service teachers for Question 3

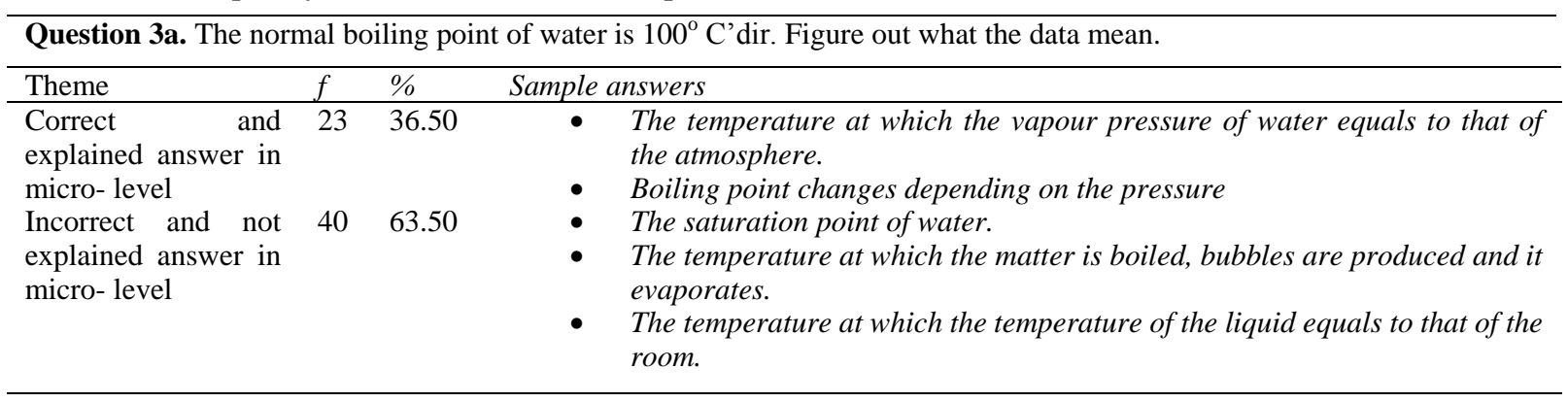




\begin{tabular}{llll}
\hline Experiment 1 & & & \\
\hline Water $\left(\mathrm{H}_{2} \mathrm{O}\right)$ & Variable $\mathrm{A}_{1}$ & Variable $\mathrm{A}_{2}$ & Variable $\mathrm{A}_{3}$ \\
\hline Boiling Point $\left({ }^{\circ} \mathrm{C}\right)$ & 100 & 98 & 95 \\
\hline $\begin{array}{l}\text { Correct: } \\
\text { Reason: }\end{array}$ & Incorrect: & & \\
Experiment 2 & & & \\
\hline Water $\left(\mathrm{H}_{2} \mathrm{O}\right)$ & & Variable $\mathrm{B}_{2}$ & Variable $\mathrm{B}_{3}$ \\
\hline Boiling Point $\left({ }^{\circ} \mathrm{C}\right)$ & Variable $\mathrm{B}_{1}$ & 102 & 105 \\
\hline Correct: & 100 & & \\
\hline
\end{tabular}

Reason:

The table above is the data obtained as a result of two different experiments conducted to identify the factors that affect the boiling point of water. The data tables display the change in the boiling points of water based upon a factor (variable). In Experiment 1, it can be observed that the boiling point of water drops depending upon Variable A; in Experiment 2, the boiling point of water rises depending upon Varible B. Do you think there is an error in the data tables? If yes, circle "correct" or "incorrect" and explain the reasons for your error. Say separately what your opinion is about two experiments.

\begin{tabular}{llll}
\hline Experiment 1 & $f$ & Sample answer
\end{tabular}

\begin{tabular}{lllll}
\hline Question 3b. & & & \\
Correct & and 7 & $11.11 \quad$ - The boiling point of water falls. The pressure decreases.
\end{tabular}

explained answer in micro- level micro- level
Incorrect and not $59 \quad 93.65$ explained answer in

- The boiling point of water falls. The pressure decreases.

- $\quad$ The boiling point of water falls. When we add alcohol to water, its boiling point decreases because alcohol is volatile.

- I agree with that. The density decreases along with the temperature. The particle number decreases. Less energy is needed to evaporate.

- $\quad$ The boiling point of water may decrease. When the pressure and impurity decrease, the density of the matter decreases, as well.

- $\quad$ The boiling point of water does not change because boiling point is a noncharacteristic property.

\begin{tabular}{lllll}
\hline Experiment 2 & $f$ & $\%$ & Sample answers \\
\hline $\begin{array}{l}\text { Correct and } \\
\text { explained answer in }\end{array}$ & 2 & 3.17 & $\bullet$ & $\begin{array}{l}\text { The pressure is increased. When the pressure of atmosphere rises, that of } \\
\text { vapour increases, as well. }\end{array}$
\end{tabular}

micro- level

Incorrect and not $61 \quad 96.82$ explained answer in micro- level
- $\quad$ Salt is added and its density increases. Bond number increases. More energy is needed to break off them.

- Boiling point does not change. It is a non-characteristic property of matter. It does not change depending on a physical alteration.

- $\quad$ Salt is added / impurity

- $\quad$ The temperature is decreased, density is increased.

- $\quad$ Temperature, density, pressure

\begin{tabular}{|c|c|c|c|}
\hline \multicolumn{4}{|c|}{ Question 3c. The table below indicates the normal boiling point values of three liquids. Interpret the data in the table. } \\
\hline Liquid & & Boili & point \\
\hline Ethoxyethan & & $34.6^{\circ}$ & \\
\hline $\mathrm{N}$-penthanol & & $138^{\circ}$ & \\
\hline Olive oil & & $200^{\circ}$ & \\
\hline Theme & $f$ & $\%$ & Sample answers \\
\hline $\begin{array}{l}\text { Correct and } \\
\text { explained answer in } \\
\text { micro- level }\end{array}$ & 29 & 46.03 & $\begin{array}{l}\text { - The one with greater attraction between its particles has different boiling } \\
\text { point. }\end{array}$ \\
\hline $\begin{array}{l}\text { Incorrect and not } \\
\text { explained answer in } \\
\text { micro- level }\end{array}$ & 34 & 53.97 & $\begin{array}{l}\text { - The one with weak attraction has lesser density. Its boiling point is lower, } \\
\text { too. } \\
\text { Because the attraction between particles is different, its particle number } \\
\text { is different, so its density is higher. More bonds should be broken off. } \\
\text { More energy is needed to break off them. Its boiling point is high. } \\
\text { Boiling point is a non- characteristic property. Each liquid has different } \\
\text { boiling points. } \\
\text { The one with greater mass has higher density and boiling point. Both are } \\
\text { non- characteristics. They are connected with each other. }\end{array}$ \\
\hline
\end{tabular}

Approximately $36 \%$ of the pre-service teachers interpreted what boiling points mean in the third question correctly and $46 \%$ of them correlated the difference between boiling points of different liquids with the attraction between the particles correctly. $12.70 \%$ of them explained that the melting and boiling points were the saturation point of the matter. $25.40 \%$ of 
them stated that the given temperature specifically defines that matter. While comparing the melting and boiling points of two matters, $20.63 \%$ of them correlated with particle number/density and $14.29 \%$ of them correlated with the mass of atom or molecule. In the second part of this question (3b), the most common misconception was that the characteristic of the mixture composed of the solute added to the solvent is the characteristic of the pure substance. For example, when salt is added to water, the boiling point of the solution but not that of water will rise. While there is a dipole-dipole interaction between water molecules, there is a stronger ion - dipole force in the mixture of salt and water that is than that of dipole-dipole. Under these circumstances, more energy is needed to overcome ion-dipole forces during the boiling process. The reason for the elevation of the boiling point is ion-dipole attraction between solvent and solute which is stronger than that of dipole-dipole between solvent particles. Because the vapour pressure of the mixture is higher than that of pure water in the mixture of alcohol and water, the boiling point of the mixture will be lower than that of pure water when alcohol is added to it. When volatile liquid is poured into water, the characteristic of the mixture emerges. $53.97 \%$ of them believed that when a foreign substance is added to water, the change in the melting and boiling points depends water.

\section{Discussion and Suggestions}

The findings suggest that pre-service chemistry teachers have a poor understanding about density, melting and boiling. More than $50 \%$ of them failed to answer the questions about density, melting and boiling significantly and correctly and could not interpret the concepts of underlying the data and units in the micro level accurately. Similar misconceptions were also encountered in the literature (Bunce \& Gabel, 2002; Pınarbas1, Sozbilir, \& Canpolat, 2009; Sanger, 2000).

It has been found that most of them could not go beyond especially the concept of density formula and they had heuristic and unscientific misconceptions about the definitions of the concept and the interpretations about relevant data. For example, one of them describes "density of the particle" as the excess in the number of the particles (URL). This may be due to his/her failure to interpret " $\mathrm{g} \mathrm{mL}$ " unit as the amount of substance in unit volume.

Generally, they either used indexical expressions without justification or were not able to offer valid reasons for those expressions in response to the questions. Most of the preservice teachers made generalizations in the process of learning the chemistry. They just learned the formulas and theories given in the learning process by heart without understanding the underlying concepts. They just concentrated on memorizing the formulas and theories given without trying to comprehend them. Therefore, they tried to apply the same strategies and interpretations automatically (Talanquer, 2006). Gabel (1999) highlighted that teachers prefer to pass from the macro level directly to the representational level without conceptualizing at micro level and intending to develop science process skills.

Interpretation requires creative thinking that results in the invention of conceptual umbrellas that can encompass the data. This process refers to the intrinsic ability to recognize patterns and associations within an enormous body of data. Interpreting the data correctly needs having correct conceptual patterns. In this respect, data with table and graph can be used to determine the level of conceptual understanding of learners and misconceptions they hold (Gultepe, 2016).

The findings confirmed significantly that most of them had certain misconceptions about the concepts. The most widespread misunderstanding was that the pre-service teachers was explaining the reason for the difference in the densities of different substances without considering the density of the particle, relating them to the melting and boiling points of the substances or spotting the difference in the number of particles. Most of them could not interpret how data on the density, melting and boiling temperatures were changed using correct variables under which conditions. According to Martin (1997), the more a teacher has an improved skill, the better she/he has skills in interpreting experimental data (cited by Basdag, 2006).

Literature studies reveal that pre-service chemistry teachers did not grasp the basic concepts of chemistry as in the students (Aydemir, Bektas, Cetin-Dindar, Aydin and Boz, 2008). The findings suggest that participant pre-service teachers did not have enough knowledge of the cognitive structures on the subject of density, freezing and boiling points and develop skills in interpreting the data since they mostly demonstrated associations in the form of definitions, for example, "density/melting point/boiling point are non-characteristics".

Students' misconceptions should be determined and eliminated beginning from the elementary school years because they bring these misconceptions to their subsequent academic levels negatively affecting their cognitive structures (Costu, Ayas, \& Unal, 2007). It is important to determine what kind of conceptions the pre-service chemistry teachers have and how they interpret the chemistry concepts through data and their level of scientific literacy since they will teach chemistry to the future generations. These concepts play a crucial role in their understanding of chemistry. More importantly, if they are well educated in the subject of chemistry, then they will be helpful for their students (Tirosh, 2000).

We indicate what we understand from them when interpreting the data. A student with developed data at interpretation 
skill has the skills in understanding what tables and graphs show, in interpreting by using the data acquired and in concluding with his/her interpretation. In fact, the skill in stating the data correctly and meaningfully needs using efficiently variable identification and change in a qualitative and quantitative aspect during the scientific process. Most data represent variables that can change their value. All series of numerical values will represent some variables that will underlie the set of values (Sharma, 2014). In the current study, from the statement in Question 1a, two pre-service teachers inferred that density "at $20^{\circ} \mathrm{C}$ " relates to temperature or from the statement in Question $3 \mathrm{~b}$, five pre-service teachers inferred that "normal boiling point" relates to pressure. The pre-service teachers, who interpret the density, melting and boiling points in a scientific language and employ units relating to these concepts, might explain the reasons for these comparisons and the changes in the values correctly.

Authentic experiences using real data in the classroom are prepared students to use these data in an effective and responsible manner in their life. Students need opportunities to employ their skills in various contexts. Students may use instruments of data analysis in all classes and their daily life so that they construct models to come up with reasonable explanations for real-world situations. Yet, it is rather clear in the researches that only exposure to situations that require such thinking does not solely have a great impact on their thinking skills (Swartz, 2000). These skills should be taught through modelling, guided practice and education. While students work on projects on data which need thinking of the data, teachers should specify specific skills that students will require to apply in different stages of the projects. These skills such as identifying patterns, inferring and transferring mathematical processes can be taught through the modelling of skills and strategies necessary for completing some tasks. While students use new skills to work with data in the projects that make sense, teachers assess their sufficiency in informal ways and conclude with additional teaching and modelling if necessary. When such a thinking forms an integral part of the classroom process, students learn to perceive thinking with data as an instrument that helps them to make sensible decisions. In this respect, teacher training should pursue the goal of educating scientific literate individuals and literate individuals and an academical life which help them develop their occupational skills and efficiency should be provided for pre-service teachers (Swartz, 2000).

Education programs should also dedicate time and effort to allow teachers to develop conceptions, construct their cognitive structures about concepts correctly regarding both their content knowledge, pedagogical content knowledge and develop their scientific process skills during pre-service and in-service training (Inan, 2010; Sinan \& Usak, 2011; Valanides, 2000).

Teacher training programs have generally not addressed data skills and data-based decision-making processes. Understanding the nature of teachers' proficiencies and difficulties in the data use is important to provide appropriate training and support for teachers because they are expected to use student data as a basis for an improvement in their practice. This improvement on skills in reading and interpreting data and units can be ensured that observation and measurement apply efficiently. In this respect, enriched learning environments through the inquiry-based learning and life-based practices in the laboratory should aim to increase both students' self-sufficiencies in these skills and their pedagogical content knowledge. For teachers to carry out the science learning activities in an efficient and meaningful way, it may be useful for actively implementing the practices of using the data and units in the classroom environments and presenting these practices to students' attention of in every stage of teaching.

\section{References}

Altusoy, S. (2008) Ortaöğretim biyoloji öğretiminde araştırmaya dayalı öğrenme yaklaşımının öğrencilerin bilimsel süreç becerilerine, akademik başarılarına ve tutumlarına etkisi (Yayınlanmamış yüksek tezi). YÖK Tez Merkezi [Effect of the research-based learning approach to the student' scientific process skills, academic achievement and attitudes in secondary biology education (Unpublished master thesis). COE Thesis Center].

Ango, M. L. (2002). Mastery of science process skills and their effective use in the teaching of science: An educology of science education in the Nigerian context. International Journal of Educology, 16(1), 11-30.

Aydemir, N., Bektas, O., Cetin-Dindar, A., Aydın, S., \& Boz, Y., (2008). Development of Pre-service Chemistry Teachers' Understanding of Particulate Nature of Matter. A paper presented XIII.IOSTE Symposium September 21-26, İzmir, Türkiye.

Basdag, G. (2006). 2000 yll fen bilgisi dersi ve 2004 yll fen ve teknoloji dersi ögretim programlarının bilimsel süreç becerileri yönünden karşılaştırılması (Yaınlanmamış yüksek lisans tezi). YÖK Tez Merkezi [Comparing 2000 science courses and 2004 science and technology in terms of the scientific process skills teaching program (Unpublished master thesis). COE Thesis Center].

Budak, I., \& Budak, A. (2013). Nicel, nitel ve karma Araştırmalarda Örnekleme. In M. Bütün, S.B. Demir, (Eds.), Eğitim araştırmalart: Nicel, nitel ve karma yaklaşımlar, 215-242, Ankara, Eğiten Kitabevi [Quantitative, qualitative and mixed survey sampling. In all M., S. B. Iron, (Eds.), Educational research: Quantitative, qualitative and mixed 
approaches, 215-242, Ankara Training bookstore].

Bunce, D. M., \& Gabel, D. (2002). The differential effects of teaching the particulate nature of chemistry on the achievement of men and women. Journal of Research in Science Teaching, 39(10), 911-927.

Cimer, A. (2012). What makes biology learning difficult and effective: Students' views? Educational Research and Reviews, 7(3), 61-71. http://dx.doi.org/10.5897/ERR11.205

Costu, B., Ayas, A., \& Ünal, S. (2007). Kavram yanılgıları ve olası nedenleri: Kaynama kavramı [Misconceptions about boiling and their possible reasons]. Kastamonu Eğitim Dergisi [Journal of Kastamonu], 15(1), 123-136.

Esme, G. (2004). Fen Öğretiminde Sorunlar. Özel Okullar Birliği Bülteni, Maltepe. Üniversitesi [Issues in Science Teaching. Private Schools Association Bulletin, Maltepe University], İstanbul. www.Özelokullarbirliği.org.tr.

Friel, S. N., \& Bright, G. W. (1998). Teach-Stat: A model for professional development in data analysis and statistics for teachers K-6. In S. P. Lajoie (Ed.), Reflections on statistics: Learning, teaching, and assessment in grades K-12 (pp. 89-117). Mahwha, NJ: Erlbaum.

Gabel, D. (1999). Improving teaching and learning through chemistry education research: A look to the future. Journal of Chemical Education, 76, 548. http://dx.doi.org/10.1021/ed076p548.

Gultepe, N. (2016). Reflections on high school students' graphing skills and their conceptual understanding of drawing chemistry graphs. Educational Sciences: Theory and Practice 16(1), 53-81. http://dx.doi.org/10.12738/estp.2016.1.2837.

Gultepe, N., \& Kilic, Z. (2015). Effect of scientific argumentation on the development of scientific process skills in the context of teaching chemistry. International Journal of Environmental \& Science Education, 10(1), 111-132. http://dx.doi.org/ 10.12973/ijese.2015.234a.

Gultepe, N., Yalcın Celik, A., \& K1lıc, Z. (2013). Exploring effects of high school studens' mathematical processing skills and conceptual understanding of chemical concepts on algorithmic problem solving. Australian Journal of Teacher Education, 38(10), 106-122. http://dx.doi.org/ 10.14221/ajte.2013v38n10.1

Hill, H., Ball, D. L., \& Schilling, S. (2008). Unpacking "pedagogical content knowledge": Conceptualizing and measuring teachers' topic-specific knowledge of students. Journal for Research in Mathematics Education, 39(4), 372-400.

Inan, H. Z. (2010). Examining pre-school education teacher candidates' content knowledge and pedagogical content knowledge. Educational Sciences: Theory and Practice, 10(4), 2275-2323.

Inan, H. Z., \& Inan, T. (2015). 3Hs Education: Examining hands-on, heads-on \& hearts-on early childhood science education. International Journal of Science Education, 37(12), 1974-1991. http://dx.doi.org/10.1080/09500693.2015.1060369

Karslı, F., Sahin, C., \& Ayas, A. P. (2009). Determining science teachers' ideas about the science process skills: A case study. Procedia Social and Behavioral Sciences, 1, 890-895. http://dx.doi.org/ 10.1016/j.sbspro.2009.01.158.

Konald, C., \& Higgins, T. L. (2003). Reasoning about data. In J. Kilpatrick, W. G. Martin, \& D. Schifter (Eds.), A research companion to principles and standards for school mathematics (pp. 193-215). Reston, VA: NCTM.

Laugksch, R. C., \& Spargo, P. E. (1996). Development of a pool of scientific literacy test-items based on selected AAAS literacy goals. Science Education, 80(2), 121-143. http://dx.doi.org/10.1002/(SICI)1098- I

Lee, Y., \& Ertmer, P. A. (2006). Examining the effect of small group discussions and question prompts on vicarious learning outcomes. Journal of. Research Technology Education, 39(1), 66-80. http://dx.doi.org/10.1080/15391523.2006.10782473

Miles, E. (2010). In service elementary teachers'familiarity, interest, conceptual knowledge, and performance on science process skills (Unpublished Master Thesis). Southern Illinois University Carbondale, USA. Available from Proquest, UMI Dissertations Publishing, (UMI No. 1482656).

Myers, B. E., Washburn S. G., \& Dyer, J. E. (2004). Assessing agriculture teachers' capacity for teaching science integrated process skills. Journal of Southern Agricultural Education Research, 54(1).

Oloruntegbe, K. O., \& Omoifo C. N. (2000) Assessing process skills in STME Going Beyond Paper and Pencil Tests, Educational Thoughts, 1(1), 25-36.

Osborne, R. J., \& Cosgrove, M. M. (1983). Children's conceptions of the changes of state of water. Journal of research in science teaching, 20(9), 825-838. http://dx.doi.org/ 10.1002/tea.3660200905. 
Pekmez, E. S. (2001). Fen öğretmenlerinin bilimsel süreçler hakkındaki bilgilerinin saptanması [The determination of knowledge about science process skills]. Paper presented at the Science Education Symposium in Turkey at the beginning of the Millennium, Maltepe University, Education Faculty, 7-8 September, Istanbul, 543-549.

Pınarbas1, T., Sozbilir, M., \& Canpolat, N. (2009). Prospective chemistry teachers' misconceptions about colligative properties: boiling point elevation and freezing point depression. Chemistry Education Research and Practice, 273-280. http://dx.doi.org/ 10.1039/B920832C.

Rubin, A. (2005). Math that matters. Hands On: A Journal for Mathematics and Science Educators, 28(1), 3-7.

Sanger, M. J. (2000). Using Particulate drawings to determine and improve students' conceptions of pure substances and mixtures. Journal of Chemical Education, 77(6), 762-766. http://dx.doi.org/ 10.1021/ed077p762.

Serin, G. (2009). The effect of problem based learning instruction on 7th grade students' science achievement, attitude toward science and scientific process skills (Unpublished doctoral dissertation). Middle East Technical University, Ankara, Turkey.

Sharma, A. (2014). How to prepare for data interpretation for Cat. Mcgraw Hill Education (India) Writing Edge Series (2nd Edition).

Sinan, O., \& Usak, M. (2011). Evaluating of Prospective biology teachers' scientific process skills. Mustafa Kemal Üniversitesi Sosyal Bilimler Enstitüsü Dergisi, 8(15), 333-348.

Swartz, R. J. (2000). Thinking about decisions. In A.L. Costa (Ed Developing minds: A Resource book for teaching thinking (pp. 58-66). Alexandria, VA: ASCD.

Talanquer, V. (2006). Common sense chemistry: A model for understanding students' alternative conceptions. Journal of Chemical Education, 83(5), 811-816. http://dx.doi.org/ 10.1021/ed083p811

Tan, M., \& Temiz, B. K. (2003). Fen öğretiminde bilimsel süreç becerilerinin yeri ve önemi. Pamukkale Üniversitesi Eğitim Fakültesi Dergisi[Importance of science process skills in science teaching. Journal of Pamukkale University Education Faculty], 1, 89-101.

Tatar, N. (2006). Illköğretim fen eğitiminde araştırmaya dayalı öğrenme yaklaşımının bilimsel süreç becerilerine, akademik başarlya ve tutuma etkisi (Doktora Tezi). Gazi Üniversitesi Eğitim Bilimleri Enstitüsü [Effect of the research based lerarning approach to the scientific process skills, academic achievement and attitudes in primary science education (Unpublished doctoral dissertation.). Gazi University Institute of Educational Sciences], Ankara.

Tirosh, D. (2000). Enhancing prospective teachers' knowledge of children's conceptions: The case of division of fractions. Journal for Research in Mathematics Education, 31 (1), 5-25. http://dx.doi.org/10.2307/749817

Turpin, T., \& Cage, B. N. (2004). The effects of an integrated activity-based science curriculum on student achievement, science process skills and science attitudes. Electronic Journal of Literacy Through Science, 3, 1-15.

Valanides, N. (2000). Primary student teachers' understanding of the particulate nature of matter and its transformations during dissolving. Chemistry Education: Research and Practise in Europe, 1(2), 249-262. http://dx.doi.org/10.1039/A9RP90026H

Warburton, E. C. (2008). Changes in dance teachers' beliefs about critical thinking activities, Journal of Education and Human Development, 2(1), 116. http://dx.doi.org/10.1080/15290824.2008.10387353.

This work is licensed under a Creative Commons Attribution 3.0 License. 